\title{
光学活性カルボニル化合物への高選択的求核 付加反応を利用する鎖状化合物の立体制御法
}

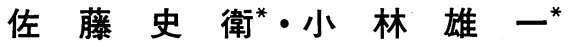

\begin{abstract}
Acyclic Stereoselection using highly Stereoselective Addition Reaction of Achiral Nucleophiles to Chiral Carbonyl Compounds.
\end{abstract}

Fumie SATO* and Yuichi KoBAYASHI*

\begin{abstract}
This article describes the attractive method for construction of acyclic systems using diastereoselective addition reactions of nucleophiles with chiral carbonyl compounds. The following topics are included:(a) the diastereofacial selective addition reaction of $\alpha$-alkyl- $\beta$-trimethylsilyl$\beta, \gamma$-unsaturated carbonyl compounds with nucleophiles and its application to the synthesis of some natural products including macrolides, (b) the addition reaction of Grignard reagents with $\alpha$ alkoxy- $\beta$-trimethylsilyl- $\beta, \gamma$-unsaturated carbonyl compounds which affords the convenient method for construction of 1,2-diol derivatives, and (c) the synthesis of the rarely obtained syn-adducts in the reaction of organocopper compounds with glyceraldehyde acetonide.
\end{abstract}

\section{1. はじめに}

カルボニル基の隣の炭素に不斉中心を有するアルデヒ ドやケトンへの求核試薬の付加反応では，(式 1 )に示し たように立体の異なる 2 つの生成物ができ，そのうち主<smiles>[R]C(=O)C([Y])([R])[R2]#N</smiles>

生成物の立体化学は Cram 則で推測される の理論的根拠となる反応時におけるカルボニル化合物の コンホメーションに関しては, 置換基の種類の違いによ り open-chain model, cyclic model そして dipolar model が提唱されている。即ち, 通常のアルキル置換力 ルボニル化合物では open-chain $\operatorname{model}(\mathrm{A})$ を, アルコ キシ基やアミノ基のような配位能力をもつ置換基を有す る場合は cyclic model (B) を, そしてハロケトン類に は dipolar model (C) を考え, それぞれ, 図に示した矢

* 東京工業大学工学部化学工学科

* Department of Chemical Engineering, Tokyo Institute of Technology

印方向から求核剤が攻撃すると考え，主生成物を推論し ようとするものである。最近では Felkin やAnh らによ り提唱された置換基の種類によらずにただひとつのモデ ルDで立体化学を説明することもよく行われている2)。

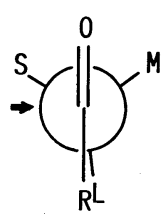

A

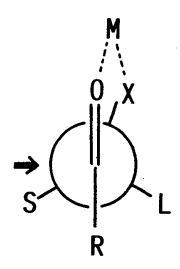

B

$x: O R, N R_{2}$

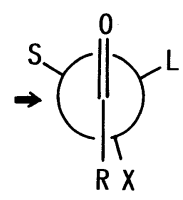

C

$X:$ halogen

さて，合成的観点からは，(式 1 )において高い選択性 が得られる反応系あるいは反応条件の探究が広く検討さ れてきた。その結果, cyclic model を経る系については 
選択性の高い反応がいろいろと見い出されている。しか し, open-chain model を経る系についてはいくつかの 例外を除いて一般には高い選択性を達成するのは困難で あるとされている。これらの成果に関しては 1983 年に Eliel により“Application of Cram's Rule : Addition of Achiral Nucleophiles to Chiral Substrates" の題 目でまとめられている゙ 。

著者らはここ数年，（式 1)で示した不斉誘導反応を有 機合成の分野におけるひとつの重要課題である "鎖状化 合物の立体制御”の方法論として利用することを考え研 究を行ってきた。ここでは, これらの研究から得られた 成果を中心にして最近のこの分野の研究の発展をまとめ てみたい。

\section{Open-chain model を経る反応の立体選択性}

$$
\text { 一マクロリド合成一 }
$$

マクロリド抗生物質は erythromycin A のアグリコン (erythronolide A) で示されるように，隣接した炭素上 に数多くの不斉中心を有し，しかも不斉炭素上にメチル 基とヒドロキシル基が相互に存在するといった特徴のあ る骨格を持っている。このような化合物の全合成を目指

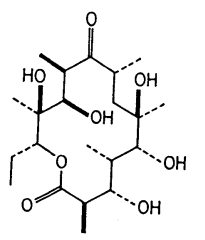

Fig. 1 The aglycone of erythromycin A.

して，隣りあったメチル基とヒドロキシル基の立体を制 御する方法論の開発が活発に行われている。その結果, アルドール反応，クロチル金属とアルデヒドとの反応に よる $\beta$-メチルホモアリルアルコールの合成, オレフィ ンのエポキシ化につづくエポキシドの開環反応，ヨード ラクトン化反応やシグマトロピー転位など数多くの方法 の有用性が明らかにされてきだ)。さて，アルキル置換 不斉カル゙ボニ化合物と求核試薬の反応における主生成 物は前述したようにCram の open-chain model あるい は Felkin-Anh model によって推測でき，例えばスキ 一ム 1 亿示したように $\alpha$-メチルアルキルアルデヒド(1) と Grignard 試薬との反応に打いては syn 型付加物 2 が，また $\alpha$-メチルアルキルケトン（3）の金属水素化物 による還元に扔いては anti 型化合物 4 が主生成物にな る。それゆえ，この反応は，隣り合ったメチル基とヒド ロキシル基の立体化学を制御する方法となり得ると考え

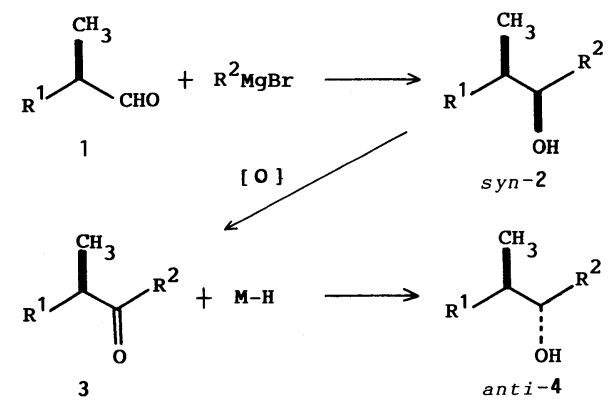

Scheme 1

られる。しかし，先にも述べたように，この種の反応の 立体選択性は一般に低く，実際には合成に応用できない と考えられてきた。しかしながらこの方法は上述した他 の鎖状化合物の立体制御法に比べてより直接的な方法で あり，また光学活性アルデヒド 1 から出発すれば光学活 性体としての 2 や 4 を容易に合成できるという非常に魅 力的方法となる可能性をもっている。それゆ著者らは， アルデヒド 1 に工夫をこらすことによりなんとかして高 い選択性を達成しょうと考えた。一般にアルデヒド 1 の 置換基 $\mathrm{R}^{1}$ が嵩高くなるほど Cram 選択性は高くなる。 また， $\mathrm{R}^{1}$ としては不斉炭素を伸長したり，あるいは官 能基変換を可能ならしめる手掛りをもったものであるこ とが望ましい。このような観点から著者らは $\mathrm{R}^{1}$ として 1-トリメチルシリルビニル基を選んだ5)。その結果, 予 期した以上のよい結果を得ることができた。

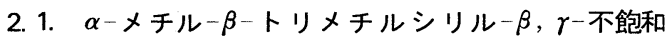

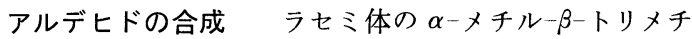
ルシリルー $\beta, \gamma$-不飽和アルデヒド (5) は（式 2)あるいは (式 3 )の方法で合成した。即ち，2-トリメチルシリル-1, 3-ブタジェンのヒドロマグネシウム化後, ギ酸のマグネ シウム塩を作用させると 5 a が，また 1-トリメチルシリ ル-1-アルキンのヒドロマグネシウム化後, $\alpha$-ブロモプロ ピオンアルデヒドを作用させると $5 \mathrm{~b}$ が得られた ${ }^{6)}$ 。
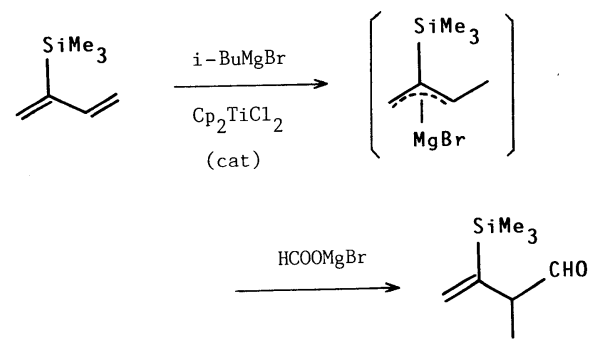


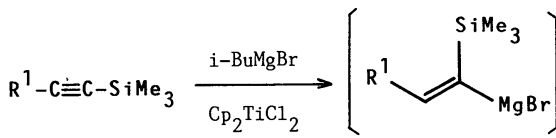
(cat)<smiles>[R]C=C([AsH2])C(C)C=O</smiles>

$5 b$
5 が合成できた。この合成法はクロチルアルコール以外 の各種アリルアルコール類を用いることによりメチル基

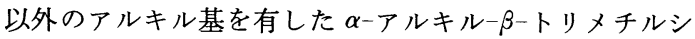
リル $\beta, \gamma$-不飽和アルデヒドが合成できること，またア ルデヒド 5 の両方のエナンチオマーが容易に合成できる などフレキシビリティーに富んでいる方法である ${ }^{8)}$ 。ま

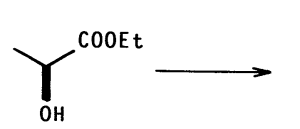

アルデヒド 5 の光学活性体の合成法をスキーム 2 に示 した。クロチルアルコールの不斉 Sharpless 反応で生成 したエポキシアルコール6のエポキシ環を1-トリメチ ルシリルビニルグリニャール試薬 ${ }^{7)}$ で位置特異的に開環 した後, ジオール部分を $\mathrm{NalO}_{4}$ で酸化的に切断すると

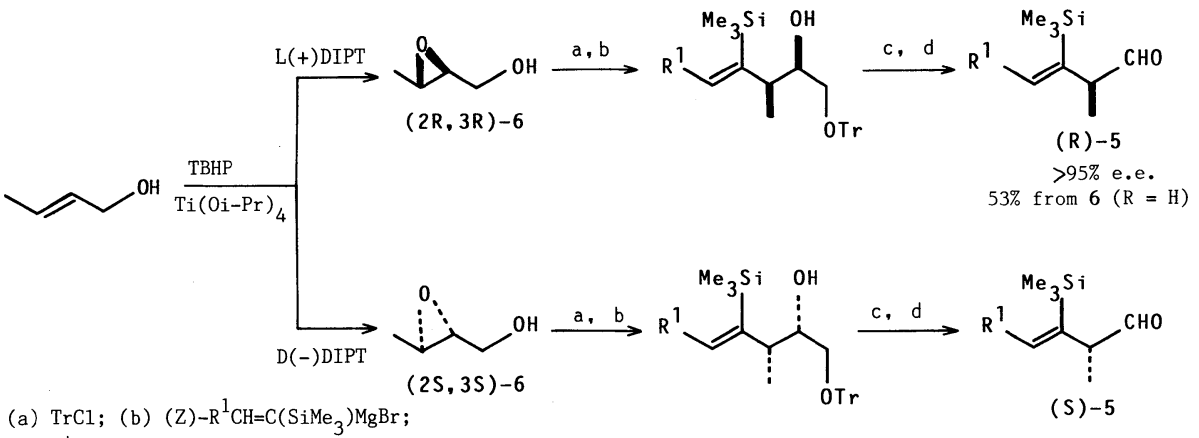

(c) $\mathrm{H}^{+}$; (d) $\mathrm{NaIO}_{4}$

Scheme 2

Table 1 Results of nucleophilic addition to the carbonyl compounds 5 and 9.

\begin{tabular}{|c|c|c|c|c|c|c|c|c|}
\hline \multicolumn{3}{|c|}{ Carbonyl compound } & \multirow{2}{*}{ Nucleophile } & \multicolumn{3}{|c|}{ Major product ${ }^{a}$} & \multirow{2}{*}{$\begin{array}{c}\text { Ratio }^{a)} \\
8: 10\end{array}$} & \multirow{2}{*}{$\begin{array}{l}\text { Yield } \\
(\%)^{\mathrm{b})}\end{array}$} \\
\hline & $\mathrm{R}^{1}$ & $\mathrm{R}^{2}$ & & & $\mathrm{R}^{1}$ & $\mathrm{R}^{2}$ & & \\
\hline $5 a$ & $\mathrm{H}$ & & $\mathrm{MeMgI}$ & $8 a$ & $\mathrm{H}$ & $\mathrm{Me}$ & $91: 9$ & 84 \\
\hline $9 a$ & $\mathrm{H}$ & $\mathrm{Me}$ & $\mathrm{NaBH}_{4}$ & $10 a$ & $\mathrm{H}$ & $\mathrm{Me}$ & $5: 95$ & 98 \\
\hline $5 a$ & $\mathrm{H}$ & & $\mathrm{Et} \mathrm{MgBr}$ & $8 b^{()}$ & $\mathrm{H}$ & Et & $>99:<1$ & 92 \\
\hline $9 \mathrm{~b}$ & $\mathrm{H}$ & Et & $\mathrm{NaBH}_{4}$ & $10 b^{d)}$ & $\mathrm{H}$ & Et & $<1:>99$ & 97 \\
\hline 5 a & $\mathrm{H}$ & & $\operatorname{Pr}^{i} \mathrm{MgBr}$ & $8 \mathrm{c}$ & $\mathrm{H}$ & $\operatorname{Pr}^{i}$ & $>99:<1$ & 91 \\
\hline $9 \mathrm{c}$ & $\mathrm{H}$ & $\operatorname{Pr}^{\mathrm{i}}$ & $\mathrm{NaBH}_{4}$ & $10 \mathrm{c}$ & $\mathrm{H}$ & $\operatorname{Pr}^{i}$ & $<1:>99$ & 96 \\
\hline $5 a$ & $\mathrm{H}$ & & $\mathrm{PhMgBr}$ & $8 d$ & $\mathrm{H}$ & $\mathrm{Ph}$ & $>99:<1$ & 94 \\
\hline $9 d$ & $\mathrm{H}$ & $\mathrm{Ph}$ & $\mathrm{NaBH}_{4}$ & $10 d$ & $\mathrm{H}$ & $\mathrm{Ph}$ & $<1:>99$ & 92 \\
\hline $5 a$ & $\mathrm{H}$ & & $\mathrm{CH}_{2}=\mathrm{C}\left(\mathrm{SiMe}_{3}\right) \mathrm{MgBr}$ & $8 \mathrm{e}$ & $\mathrm{H}$ & $\mathrm{CH}_{2}=\mathrm{C}\left(\mathrm{SiMe}_{3}\right)$ & $>99:<1$ & 93 \\
\hline $5 \mathrm{~b}$ & $\mathrm{Bu}^{\mathrm{n}}$ & & EtMgBr & $8 f$ & $\mathrm{Bu}^{\mathrm{n}}$ & Et & $>99:<1$ & 83 \\
\hline $9 \mathrm{f}$ & $\mathrm{Bu}^{\mathrm{n}}$ & Et & $\mathrm{NaBH}_{4}$ & $10 \mathrm{f}$ & $\mathrm{Bu}^{\mathrm{n}}$ & Et & $<1:>99$ & 90 \\
\hline
\end{tabular}

a) The structures and ratio of the products were determined by ${ }^{1} \mathrm{H}$ and ${ }^{13} \mathrm{C}$ NMR spectroscopy and/or by GLC analysis of their protodesilylated products. b) Isolated yield after chromatography on silica gel. c) $(3 R, 4 S)-8 \mathrm{~b}:[\alpha]_{\mathrm{D}}{ }^{25}-26.9^{\circ}(c 1.04$, $\left.\left.\mathrm{CHCl}_{3}\right) ;(3 S, 4 R)-8 \mathrm{~b}:[\alpha]_{\mathrm{D}}{ }^{25}+26.2^{\circ}\left(c 1.00 . \mathrm{CHCl}_{3}\right) . \mathrm{d}\right)(3 R, 4 R)-10 \mathrm{~b}:[\alpha]_{\mathrm{D}}{ }^{25}-13.9^{\circ}\left(c 1.41, \mathrm{CHCl}_{3}\right) ;(3 S, 4 S)-10 \mathrm{~b}:[\alpha]_{\mathrm{D}}{ }^{25}$ $+14.0^{\circ}\left(c 0.998, \mathrm{CHCl}_{3}\right)$. 

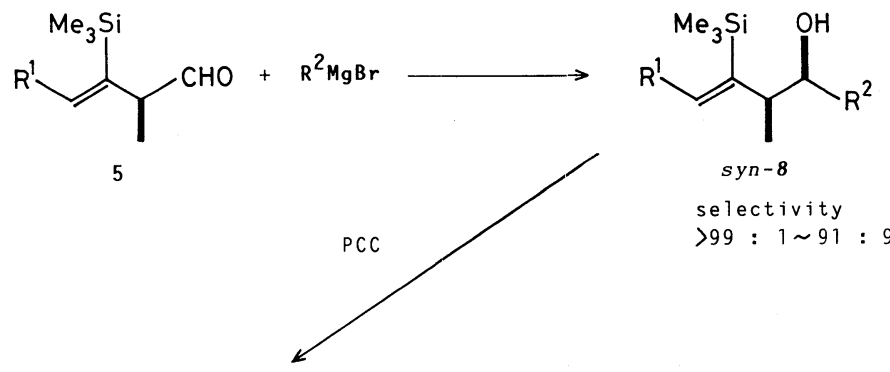

selectivity
$>99: 1 \sim 91: 9$<smiles>[R]C=C(C)C(C)C([R15])=O</smiles>

$+\mathrm{NaBH}_{4}$
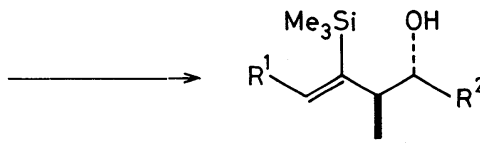

ant $i-10$

selectivity

$>99: 1 \sim 95: 5$

Scheme 4

た，土橋らはスキーム 3 に示したように乳酸エチルより 㗑いたメシラート 7 の還元的ピナコール転位を用いる方 法によって 5 を得ている

2. 2. $\beta$-メチルホモアリルアルコールおよびアルドー ルの選択的合成 上述したように得られた $\alpha$-メチル$\beta$-トリメチルシリル $\beta, \gamma$-不飽和アルデヒド 5 と Grignard 試薬との反応を検討したところ表 1 に示すように非常に 高い選択性で Cram 生成物である syn 型付加物 8 が得ら れた。即ち, $\mathrm{CH}_{3} \mathrm{MgI}$ との反応の選択性は $9: 1$ 程度で あったが，メチル以外のアルキルやアリールマグネシウ ムブロミドとの反応に打ける選択性は $99 \%$ 以上であっ た $\left.(\text { スキーム } 4)^{6}\right)$ 。得られたアルコール 8 を酸化して ケトン 9 に変えた後, 9 を $\mathrm{NaBH}_{4}$ で還元したところ, やはり反応は非常に高い Cram 選択性で進行し anti型ア ルコール 10 を与えた (表 1$\left.)^{6}\right)$ 。なお 9 型のケトンの立 体選択的還元については土橋らによっても独自に見い出 された ${ }^{10)}$ ここうして，アルデヒド 5 を原料とすることに

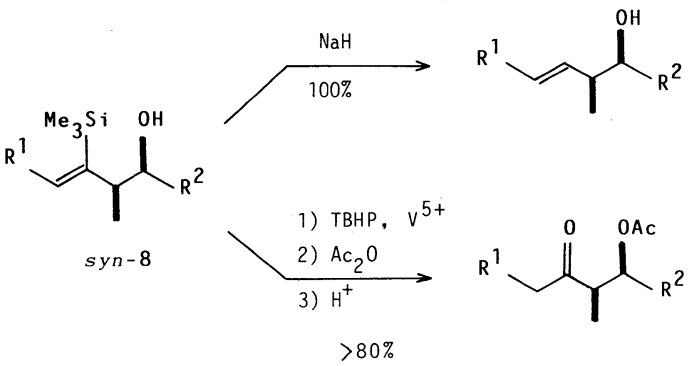

Scheme 5
より光学活性体を含めて隣り合ったメチル基とヒドロキ シル基の立体化学を任意に制御することができる有力な 方法を手にすることができた。

このようにして合成した 8,10 に室温下触媒量の $\mathrm{NaH}$ あるいは KH を作用させると容易にプロト脱シリル化が おこり ${ }^{11)} \beta$-メチルホモアリルアルコールが得られた。ま た 8, 10 は Stork 反応 ${ }^{12}$ により $\alpha$-メチル- $\beta$-ヒドロキシ ケトン誘導体にも変換できた（スキーム 5 )。

さて, アルデヒド 5 と Grignard 試薬の反忘による高 い立体選択性の発現には，トリメチルシリル基の嵩高さ 以上に $\alpha$ 置換ビニル基の存在が大きな役割を担ってい

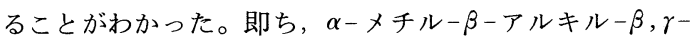
不飽和アルデヒド 11 と Grignard 試薬の反応は, アル デヒド 5 との反応の選択性に比べると少しおちるが， それでも $93: 7$ 以上の高い選択性で進むことがわかった。 この結果と共役ジェンのヒドロマグネシウム化反応 ${ }^{7 \mathrm{a}, 13)}$ を組み合わせると立体および位置の両方を制御したアル ドール合成法となる。即ち，スキーム6に示したように クロロプレンとアルキルマグネシウムブロミドのカップ リング反応によって容易に入手しうる 2-アルキル-1, 3ブタジェンをヒドロマグネシウム化させた後, ギ酸のマ グネシウム塩と反応させてアルデヒド 11 を，あるいは ニトリルと反応させてケトン 12 を合成する。アルデヒ ド 11 と Grignard 試薬の反応で syn 型付加物 13, ケト ン 12 の L-Selectride 還元により anti 型付加物 14 を

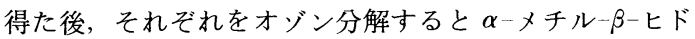
ロキシケトンの両ジアステレオマーとも合成することが できた ${ }^{14)}$ 。 


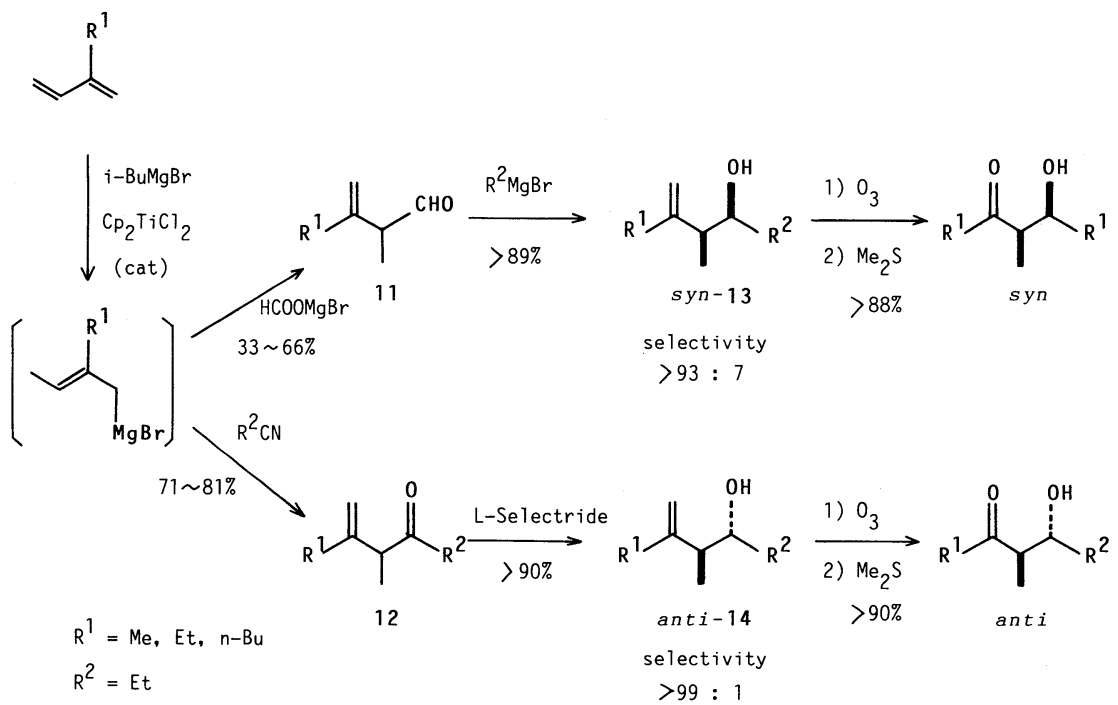

\section{Scheme 6}

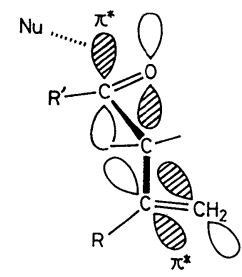

(a)

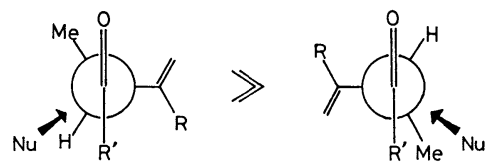

(b)

Fig. 2 (a) Stereoview of the supermolecule including the $\pi^{*}$ orbitals. (b) Direction of nucleophilic attack.

$\alpha$ 置換ビニル基が， 1,2-不斉誘導反応において単純な 立体障害から予想される以上に大きな基として寄与して いると考えられるこれらの結果は, Anh らが説明したよ うに付加反応の遷移状態におけるオレフィンとカルボ二 ル基との $\pi^{*}-\pi^{*}$ 相互作用による図 2 で示した FelkinAnh model の安定化で理解できると考えている ${ }^{2)} 。$

2. 3. 3 連続不斉中心の立体制御 アルデヒド 5 と Grignard 試薬以外の求核剤との反応も選択性高く進行 する。例えばエステルェノラートとの反応では syn 型付 加物 15 が $8: 1$ の選択性で得られた。この付加物を酸化
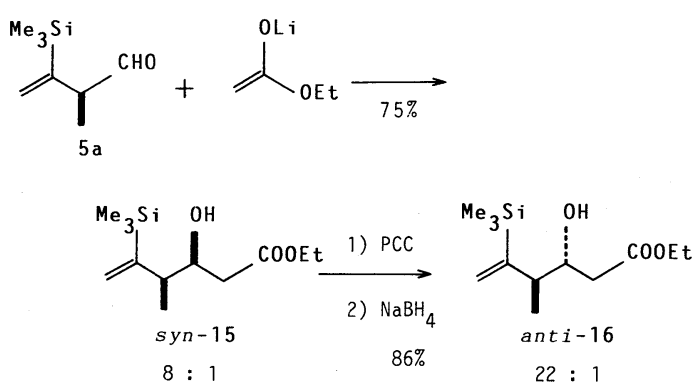

Scheme 7

し, $\mathrm{NaBH}_{4}$ 還元すると anti 型化合物 16 が選択性高く 得られた (スキーム 7$)^{15)}$ 。

最近アルドール反応の化学は大きく進歩し, アルデヒ ドとの反応でラセミ体の syn 型あるいは ant $i$ 型アルド ールを高選択的に与えるエチルカルボニル化合物のエ， ラートが種々開発されてきている(式 4$)^{16)}$ 。それゆえ,

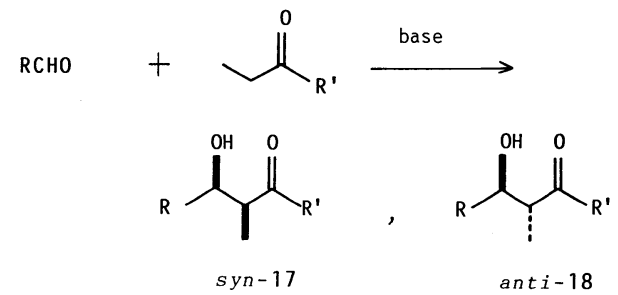

光学活性なアルデヒド 5 とこれらのエノラートを反応さ せれば 3 連続不斉中心を制御することが容易にできると 
<smiles>C=C([C@H](C)C=O)[Si](C)(C)C</smiles>

20

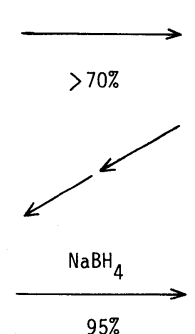

$95 \%$<smiles></smiles>

19

$>30: 1$<smiles>C=C(C)C(C)C(O)[C@@H](C)CCc1ccccc1</smiles>

21

Scheme 8

考えられる。実際に, Heathcock らにより開発された $\alpha, \beta-$ anti 型アルドールを与えるプロピオン酸 BHT エステルエ ノラート ${ }^{17}$ )を光学活性な 5 a に作用させると $\alpha, \beta$-anti, $\beta, \gamma-\operatorname{syn}$ 型アルドールの光学活性体 19 が $30: 1$ 以上の 選択性で得られた $(\text { スキーム } 8)^{15)}$ 。従来, このような 3 連続不斉中心をもつ化合物の合成は光学活性エ ノラートと光学活性アルデヒドを用いる double stereodifferentiation の考えに基づく方法で合成されて いたが $(\text { スキーム } 9)^{16)}$ ，これまでのところ $\alpha, \beta$-anti の立体化学を与える光学活性エノラートの開発には成功 しておらず $\alpha, \beta$-anti の立体化学を有する 3 連続不斉中 心の制御は困難であった。それゆえ 19 を工程で与え る本反応の合成的意義は大きい。更に 19 を 20 に変換 し, 20 を $\mathrm{NaBH}_{4}$ で還元すると今度は $\alpha, \beta-s y n, \beta, \gamma-$ anti の立体化学を有するアルドール誘導体 21 が得られ

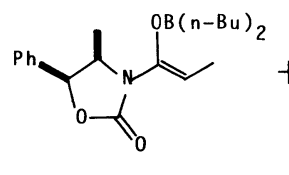<smiles>C=C(C)CC(C)C(O)C(C)C(=O)N1C(=O)O[C@H](c2ccccc2)[C@H]1C</smiles>

Scheme 9
た。アルデヒド 5 とクロチル金属の反応による 3 連続不 斉中心の立体制御も可能である(式 5$)^{18)}$ 。

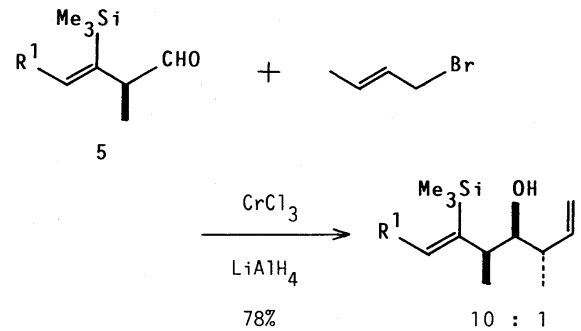

アルデヒド 5 はジチアンのアニオンともほぼ $100 \%$ の 選択性で反応して syn 型付加物 23 を与える（スキーム 10)。23のヒドロキシル基をベンジルエーテル化して保 護したのち, ジチオアセタール基をカルボニル基に変換 させ Grignard 試薬と反応させると, 後述する Stillらの 結果どおりほぼ $100 \%$ の選択率で cyclic model から予 想される Cram 生成物 24 を与た。即ち, この反応は 図 1 に示したエリスロノライド $\mathrm{A} の \mathrm{C}_{4}-\mathrm{C}_{6}$ ならびに $\mathrm{C}_{10}$ $\mathrm{C}_{12}$ に対応寸る 3 連続不斉中心の立体制御法になる ${ }^{19}$ 。<smiles>C=C([SiH3])[C@@H]([18OH])C=O</smiles><smiles>CC1SCCCS1</smiles><smiles>[R]C1(C(C)C(O)C(=C)C)CCCS1</smiles>

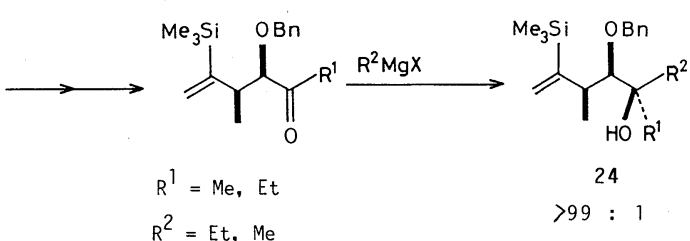

Scheme 10 
2. 4. $\gamma, \delta$-エポキシー $\beta$-メチル- $\gamma-($ トリメチルシリル)アルカノールの合成， 4 連続不斉中心の立体制御 $\left.{ }^{20}\right)$

アルデヒド 5 と各種求核試薬の反応で 2 個あるいは 3 個の連続する不斉中心の立体制御ができることを明らか にしてきたが，付加生成物中のビニルシリル基の反応性 を利用することによっても不斉中心を伸長することがで きる。それゆえ，4 あるいは 5 連続不斉中心を容易に制 御することが可能となる。

$s y n$ 型アルコール 8 を $\mathrm{VO}(\mathrm{acac})_{2}$ を触媒として用い て $t$ - BuOOH (TBHP) 酸化すると $99 \%$ 以上の高い不斉 誘導が起こり, エポキシド 25 が得られた（式 6 )。一方, 8 より導いたエステル 26 の $m \mathrm{CPBA}$ 酸化では $6: 1$ の 比で 25 とは逆の立体を有する 27 が主生成物となった (式 7)。なお, この立体選択的な反応において $\mathrm{SiMe}_{3}$ 基の存在が必須である。即ち，(式 8）に示したように $\mathrm{SiMe}_{3}$ 基のない場合，選択性はほとんど見られなかった。<smiles>[R]C=C([Si])[C@H](C)C([R])O</smiles>

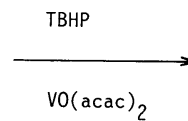

(cat)<smiles>[R]C=C(C)C(C)C([R2])C(=O)Oc1ccccc1</smiles>

26<smiles>C=C[C@H](C)[C@H](O)CC</smiles>

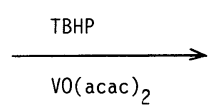

(cat)<smiles>CC[C@H](O)[C@@H](C)[C@H](O)C1CO1</smiles>
$3: 2$<smiles>[R]C(O)[C@H](C)[C@]1([SiH3])OC1[R]</smiles>

25 $>99: 1$<smiles>[R]C(O)C(C)C1([Si])OC1[R]</smiles>

27 $6: 1$<smiles>[R]C=C([SiH3])[C@@H](C)C([R2])[R]</smiles>

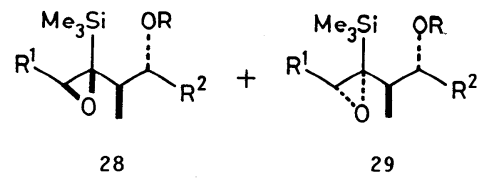
$<3: 1$
同様に ant $i$ 型アルコール 10 およびそのエステルのエ ポキシ化反応を試みた。しかし合成的には満足のいく立 体選択性は得られなかった(式 9 )。そこで 25, 27 より 誘導したケトン 30,31 の金属水素化物による還元反応 を検討することにした（式 $10 ， 11$ )。即ち 30,31 は $\alpha$,
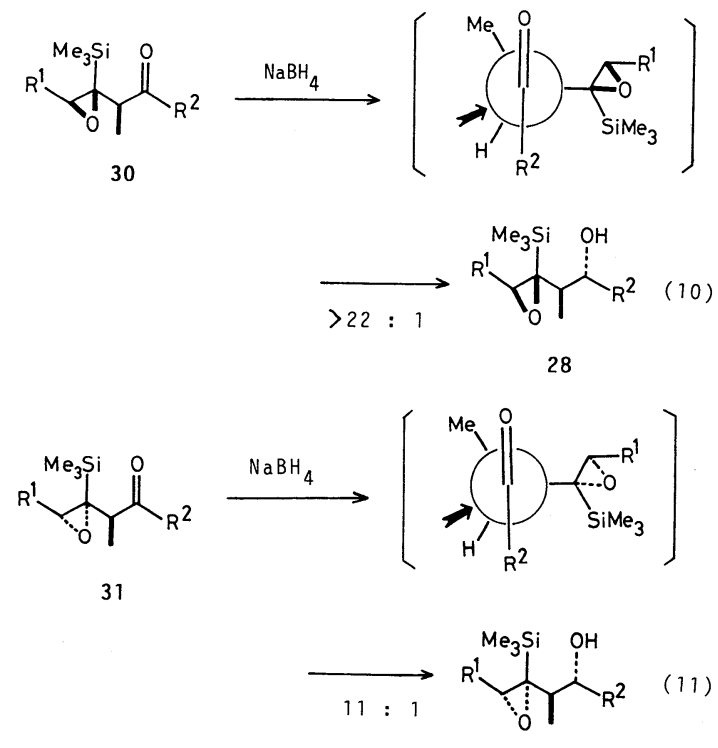

29

$\beta$-エポキシシランという非常に嵩高い基を有しているた め, 高い 1,2-不斉誘起が期待でき, 目的のアルコール 28，29 がそれぞれ生成すると考えた。実際， $\mathrm{NaBH}_{4}$ を 用いて還元反応を行うと 30 からは 28 が，また 31 から は29 が高選択的に生成した。なお, $\mathrm{SiMe}_{3}$ 基がないと 立体選択性は失われる（式 12 ）。

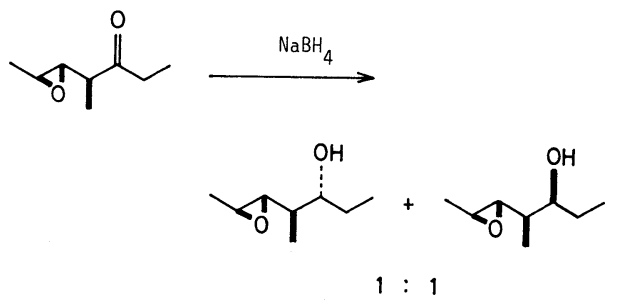

2. 5. 天然物合成への応用 これまでアルデヒド 5 に対する各種求核試薬の選択的反応について述べてきた。 ここではこの反応を用いてマクロリドやフェロモン等の 天然物合成への応用を行った結果について述べる。 タバコシバンムシの性フェロモンである serricornin $(35)^{21)}$ の合成ルートをスキーム 11 に示す。 5 a より合 成したホモアリルアルコール 32 をヒドロマグネシウム 


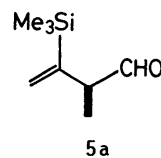

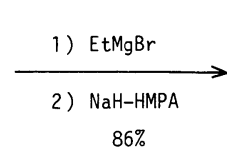<smiles>C=C[C@H](C)[C@H](O)CC</smiles>

32
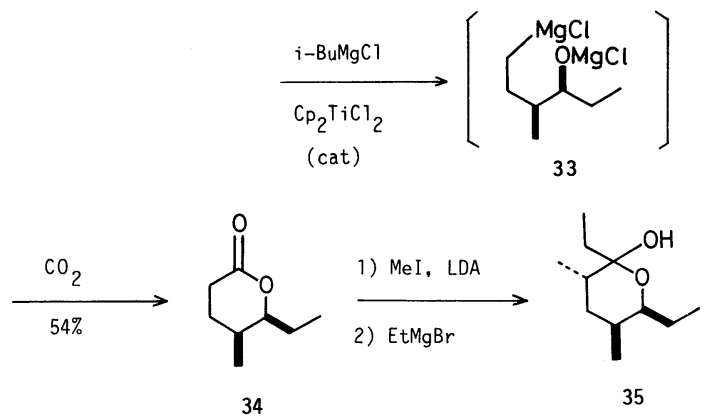

Scheme 11

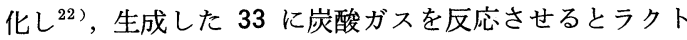
ン 34 が得られた。34をメチル化し, 続いて $\mathrm{EtMgBr}$ を反応させると 35 が合成できた ${ }^{8 \mathrm{~b}, 23)}$ 。

Mycolic acid は癌の治療の際の免疫療法剤の構成成 分として注目を集めているほか，生物学的にも興味深い 性質を有している化合物である ${ }^{24)}$ 。このものは長鎖のア ルキル基 $\mathrm{R}^{1}, \mathrm{R}^{2}$ を含む炭素数 28〜90 からなる高分子 量の化合物であり絶対配置を含め一般式 36 で示したよ うに $(2 R, 3 R)$ の立体化学を有している ${ }^{25)}$ 。これまで<smiles>[R]C(O)C([R2])C(=O)O</smiles>

mycolic acids

(36)

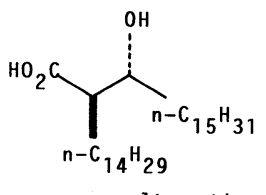

corynomycolic acid

(37)
スキーム 12 で示したようにアルドール反応を用いたラ セミ体の合成法が Heathcock らにより報告されている<smiles></smiles>

Scheme 12
が，アルキル基が長鎖のためその選択性はそれ程高くな く, この辺にアルドール反応によるアプローチの限界があ るように思われる ${ }^{17 a, 26)}$ 。我々は 36 の一種である corynomycolic acid (37) を標的化合物として選び本法による

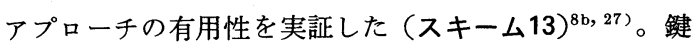
反応はケトン 39 の還元反応であり>99:1 の比で立体 選択的に進行している。なお光学活性アルデヒド 38 は (E)-2-heptadecen-1-ol を原料として 5 a の場合と同 じ方法で合成した。

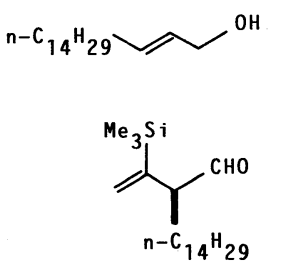

38
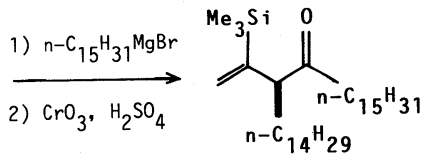

39
2) $\mathrm{CrO}_{3}, \mathrm{H}_{2} \mathrm{SO}_{4}$

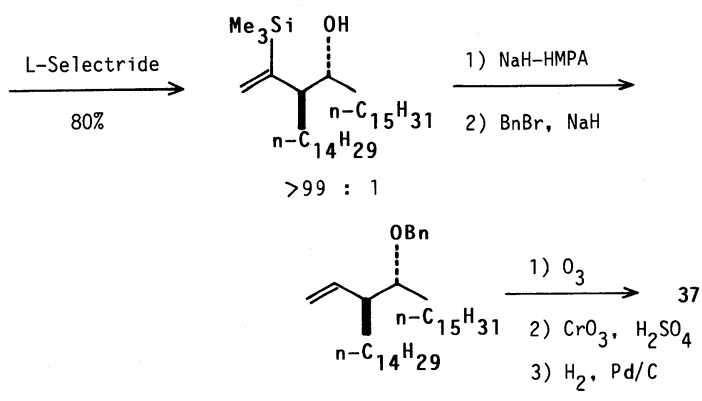

Scheme 13<smiles>CCCCCC(=O)C(C)O</smiles>
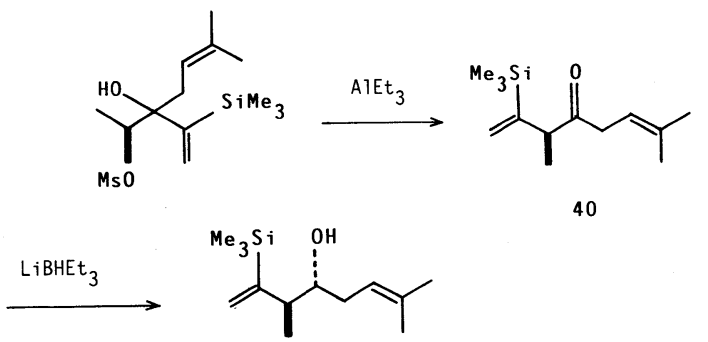

$>99: 1$

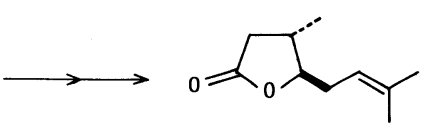

41 
フェロモンの一種 eldanolide (41) ${ }^{28)}$ がケトン 40 の 立体選択的還元反応を経て土橋らにより合成された（ス キーム 14$)^{29)}$ 。なお，ケトン 40 は $(S)$-乳酸エチルよ り不斉ピナコール転位を利用して合成されている。

抗生物質 antimycin $\mathrm{A}_{3}$ の減成化合物である blastmycinone $(45)^{30)}$ は 3 連続不斉中心を有する $\gamma$-ラクトンで

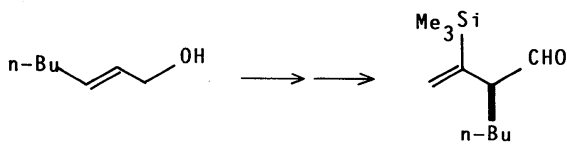

42

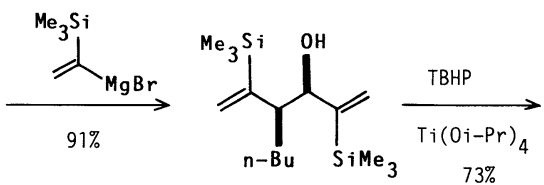

43

ある。このものの不斉中心はアルデヒド 42 に対する1トリメチルシリルビニルマグネシウムブロミドの付加な らびに付加物のエポキシ化反応ですべてほぼ $100 \%$ の立 体選択性をもって導入できた（スキーム15) ${ }^{31)}$ 。

次に我々はエリスロマイシン生合成上重要な中間体で ある 6-deoxyerythronolide $\mathrm{B}(46)^{32)} の \mathrm{C}_{(1)}-\mathrm{C}_{(7)}$ に相 当する化合物（47）の合成を行った（スキーム 16）。ク

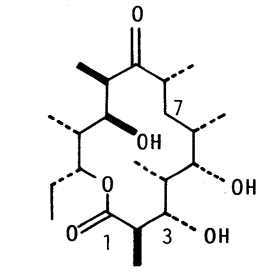

6-deoxyerythronolide B

(46)<smiles>C[C@H](CO)[C@H]1OC(C)(C)O[C@H]([C@H](C)CCc2ccccc2)[C@H]1C</smiles>

$C(1)-C(7)$ segment

(47)

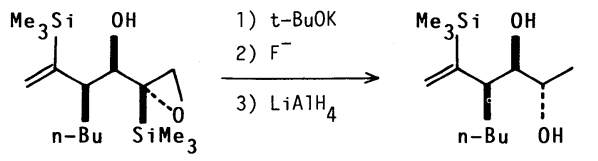

44

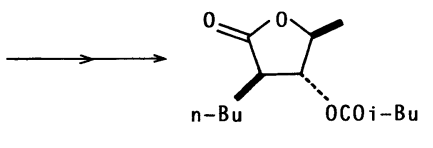

45

ロチルエポキシアルコール誘導体 48 と 1-トリメチルシ リルプロピンのヒドロマグネシウム化反応 ${ }^{7}$ で調製した Grignard 試薬 49 からスキーム 2 に準じて合成したア ルデヒド 50 にプロピオン酸 BHT エステルエノラート を反応させた後, 立体選択的なエポキシ化反応を行うと 51 のみが得られた。エポキシド 51 に1-トリメチルシリ ルビニルマグネシウムブロミドを位置特異的に反応させ， つづいてビニル基を官能基変換すると 47 が合成でき $た^{20)}$ 。

16 員環マクロリドである tylonolide $(52)^{33)}$ の右半分

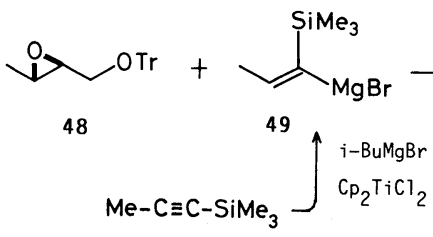<smiles>C/C=C(\[Si]=[Si])C(C)C(O)C[Br+]</smiles>

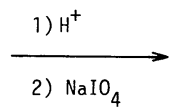<smiles>C=CC(=CC)C(C)C=O</smiles>

50

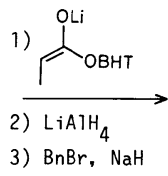

$71 \%$<smiles>C=[SiH]C(=CC)C(C)C(C)CCO</smiles>

$>30: 1$
1) $T B H P / V^{5}$

2) $t-B u O K$

$76 \%$<smiles>CC(C[Hg]Br)C([Al])C(C)C1CO1</smiles>

51

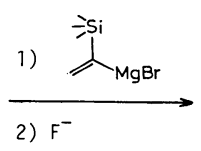

$62 \%$

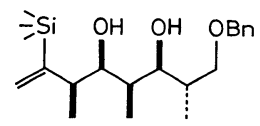

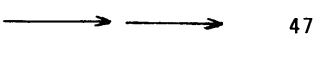

Scheme 16 


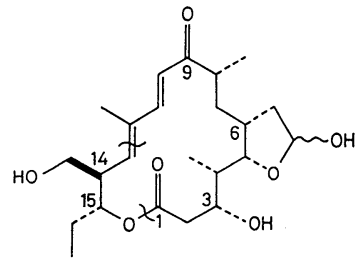

tylonolide

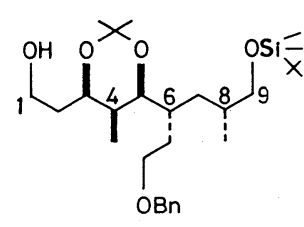

$C(1)-C(9)$ segment

(53)<smiles>C=C[C@@H](C[18OH])[13CH2]O</smiles>

$C(13)-C(17)$ segment

(54)

(52)<smiles>C=C([AsH2])C(C)C=O</smiles><smiles>C=C(C)C(C)C(O)C(CO)CCOC</smiles><smiles>C=C([AsH3])[C@H](C)[C@H]1OC(=O)[C@@H](C)C[C@H]1CCCc1ccccc1</smiles>

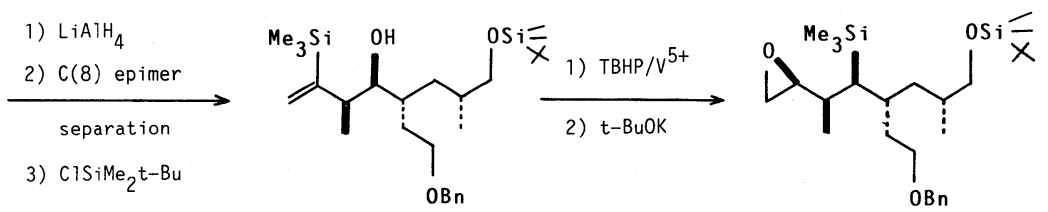

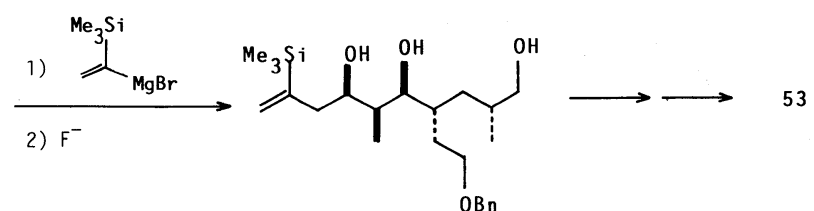

Scheme 17

$\mathrm{C}_{(1)}-\mathrm{C}_{(9)}$ に相当する 53 も 47 合成に類似した方法で合 成できた $(ス キ ー ム 17)^{34)}$ 。なお，52 の左半分 $\mathrm{C}_{(13)^{-}}$ $\dot{C}_{(17)}$ に相当する 54 はスキーム 18 に示したルートで容 易に合成できた。<smiles>OCC1CC1CBr</smiles>

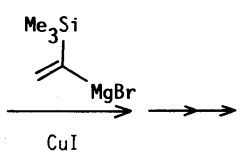

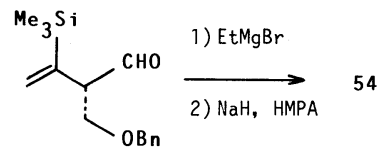

Scheme 18

Protomycinolide IV は mycinamicin 類マクロリドで あり 55 で示した構造を有する ${ }^{35}$ 。 土橋らは (式 5 ) で合
成した化合物 58 を用いて 55 の $\mathrm{C}_{(1)}-\mathrm{C}_{(9)}$ に相当する ラクトン 56 を合成した。また同時に 55 の $\mathrm{C}_{(11)}-\mathrm{C}_{(17)}$ 部分も合成している $\left(\right.$ スキーム 19) ${ }^{36 j}$ 。

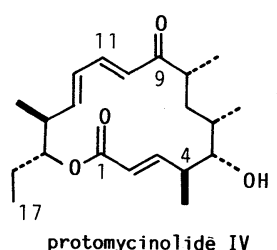

(55)

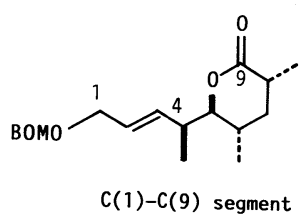

(56)

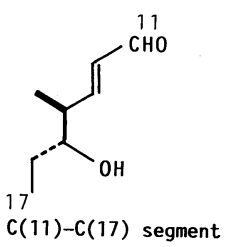

(57) 


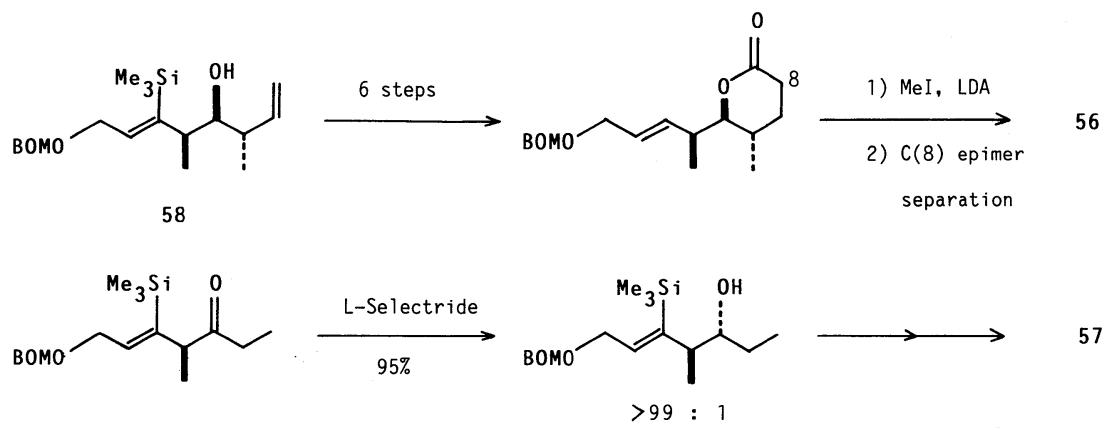

Scheme 19

\section{Cyclic model を経る反応の立体選択性}

3. 1. $\alpha$ 位にヘテロ原子を有するカルボニル化合物に 対する求核試薬の反応 1 章の冒頭で述べたように, アルコキシ基やアミノ基のような配位能力をもつ基を $\alpha$ 置換基とするカルボニル化合物と求核試薬の反応では高 い立体選択性が発現する例がかなり見出されており，天 然物合成などにも広く応用されている。そして現在でも この分野の研究は活発に行われている ${ }^{37)}$ ここでは Eliel の総説 ${ }^{3}$ 以降発表された応用範囲の高い反応例のいくつ かを紹介する。

大石・中田らはエステル基やヒドロキシル基を $\alpha$ 位に 有するケトンを $\mathrm{Zn}\left(\mathrm{BH}_{4}\right)_{2}$ を用いて還元すると Cram の cyclic model で予想される生成物が選択的に生成す ることを見出した ${ }^{38)}$ 。一例を(式 13 ) に示す。一方，蒿 高いシリルオキシ基を $\alpha$ 置換基とするケトン 61 を配位能 力のない $\mathrm{NaAlH}_{2}\left(\mathrm{OCH}_{2} \mathrm{OCH}_{2} \mathrm{CH}_{2} \mathrm{OMe}\right)_{2}$ (Vitride) で還元すると, 還元の立体化学は (式 13) の場合と比 ベて逆転し, syn 型アルコール 62 が主生成物になるこ とも明らかにしている（式 14）。これらの反応は anti-<smiles>CC(=O)[C@@H](O)[C@@H](C)C[Br+]</smiles>

59<smiles>CC(=O)[C@H](O[GaH2])[C@@H](C)C[18OH]</smiles>

61

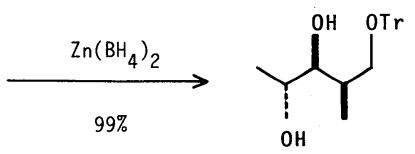

anti-60

$25: 1$

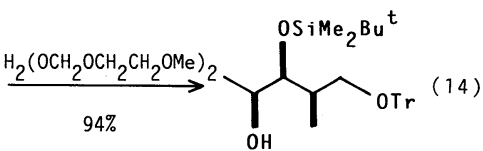

syn-62

$30: 1$ mycin $\mathrm{A}_{3}$ をはじめ, いくつかの天然物の合成に利用さ れている。

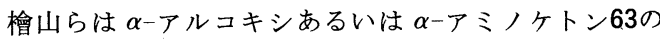
ヒドロシランによる還元反応を検討した結果, フッ素ア ニオンを用いてヒドロシランを活性化すれば syn 型アル コール 64 が，一方酸性条件下では anti 型アルコール65 がそれぞれ生成すると報告している（スキーム 20）年）。 syn 選択性はアルコキシル基を一番嵩高い置換基と見な す Cram の open-chain model で, また anti 型は cy-

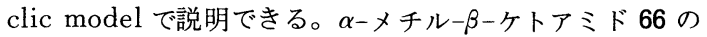

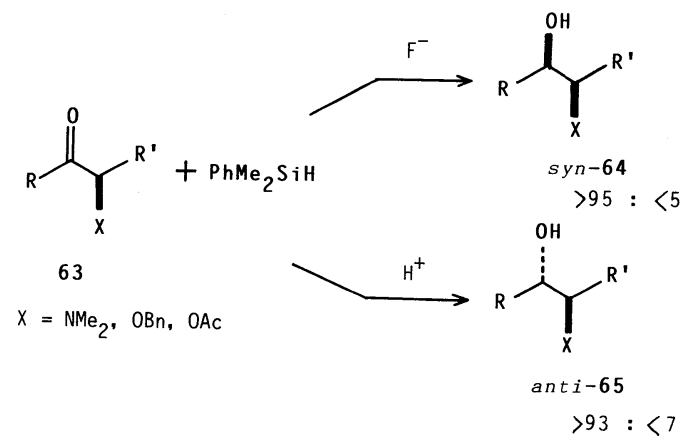

Scheme 20

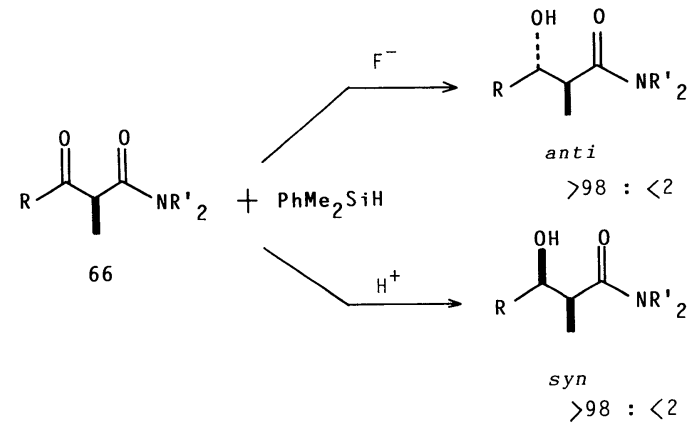

Scheme 21 
同条件下での還元反応も選択的に進行し, syn および ant $i$ 型の $\beta$-ヒドロキシー $\alpha$-メチルアミドを得ることにも成功 している(スキーム 21 $)^{40)}$ 。これらの反応の立体選択性 は高く $l$-ephedrine や $l$-methoxamine をはじめ多くの 天然物や医薬品合成への幅広い応用がなされている。

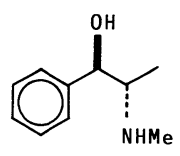

$\ell$-ephedrine

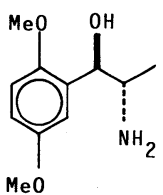

$\ell$-methoxamine

この他, 求核試薬としてエノラートアニオンあるいは その等価体との立体選択的反応も数多く発表されている が，これらについては最近の総説によくまとめられてい る37)。またグリセルアルデヒドとの反応については節を あらためて述べる。

ところで Still らは，(式 15)に示したように $\alpha$-アルコ キシケトンと Grignard 試薬との反応では条件さえ選べ ばほぼ $100 \%$ の選択性で Cram の cyclic model で予想

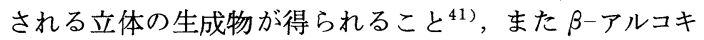
シアルデヒ、゙とクプラートとの反応も非常に高い選択性 で進むことを明らかにしている（式 16$)^{42) 。 し か し ， ~} \alpha-$

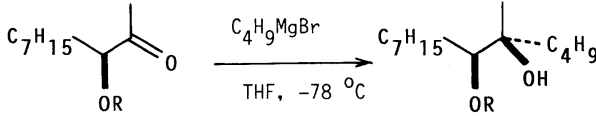

$\mathrm{R}=$ MEM, MOM, MTM, Bz, $\mathrm{CH}_{2} \mathrm{OBz} \quad>100: 1$
アルコキシアルデヒドと Grignard 試薬やクプラートと の反応はいまひとつ選択性が上がっていなかった。最近 になって $\mathrm{Mg}$ や $\mathrm{Cu}$ 以外の有機金属化合物との反応ある いはルイス酸性をもつ金属塩を添加する条件下での反応 が検討され非常に高い選択性が達成されるようになって

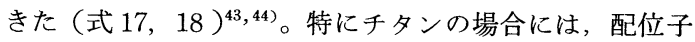

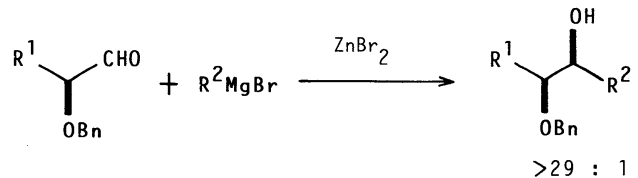

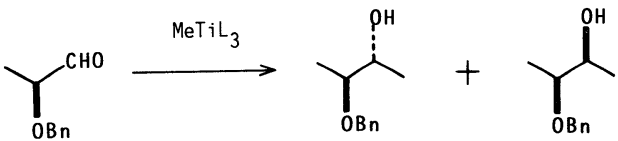

$$
\begin{array}{ll}
\mathrm{L}=\mathrm{C} 1 & 8: 92 \\
\mathrm{~L}=0 \mathrm{i}-\mathrm{Pr} & 92: 8
\end{array}
$$

を選ぶことにより反応の立体化学を任意に制御すること が可能である。

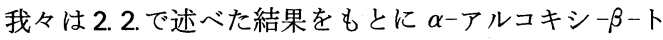
リメチルシリルー $\beta, \gamma$-不飽和アルデヒド (68) と Grignard 試薬との反応も次に述べる理由により高選択的に進行し syn 型付加物 69 を与えると予想した（式 19 )。即ち,

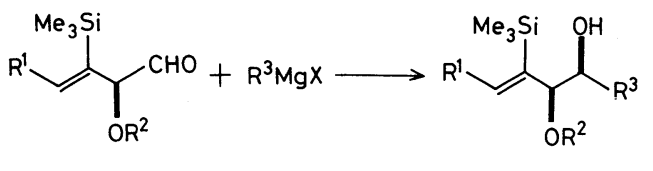

68

syn-69

この反応では Cram の cyclic model (70)を経て反応が 進行しても，あるいは1-トリメチルシリルビニル基を最 も嵩高い基として考える Felkin-Anh model (71)を経

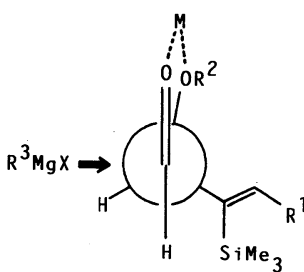

70

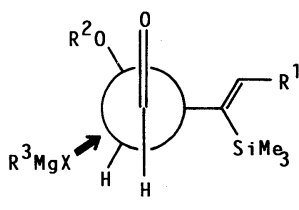

71
て反応が進行しても付加生成物は同じ立体化学を持つこ とになるからである。そして同じ理由から，69 を酸化し て得られるケトン 72 を還元すると anti 型アルコール 73 が生成すると予想した（式 20 )。

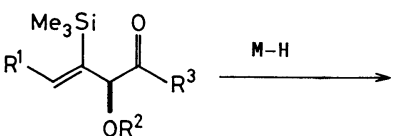

72<smiles>[R]C=C([As])C(O)C([R])O</smiles>

ant $i-73$
3. 1. 1. $\alpha$-アルコキシ- $\beta$-トリメチルシリル $\beta$, $\gamma$-不飽 和アルデヒドの合成および Grignard 試薬との反応 ア ルデヒド 68 は D-グリセルアルデヒドアセトニド (74) を原料としてスキーム 22 亿示した方法で合成した。即 ち，74 と1-トリメチルシリルビニル金属化合物を反応 
<smiles>[R]C=C([Si])[Si]C(=O)C(O)C1COC(C)(C)O1</smiles><smiles>[R]C=C([C@H](O)C1COC2(C)OC12)[Si](C)(C)C</smiles><smiles>CC</smiles>

ant $i$

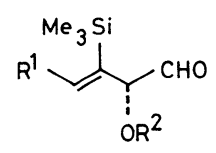

(S) -68<smiles>[R]C=C([Se])[C@H]([SiH2])C=O</smiles>

(R) -68

Scheme 22

させて得た付加物の立体異性体混合物をメチルあるいは ベンジルエーテル化した後, 両者をカラムクロマトグラ フィーで分離する。つづいて脱アセトニド, $\mathrm{NaIO}_{4}$ を用いる ジオールの酸化的切断を行いアルデヒド 68 を合成した。 こうして得た 68 の両エナンチオマーはキラルシフト試 薬を用いる NMR の測定の結果, ほぼ $100 \%$ の光学純度 であることがわかった。なお，74と1-トリメチルシリ ルビニル金属の反応において，後述（3.2.節）するよう に, syn 型, anti 型付加物をそれぞれ $95 \%$ 以上の選択 率で与える条件も見出しており，現在では $\alpha$-アルコキ シー $\beta$-トリメチルシリル- $\beta, \gamma$-不飽和アルデヒド 68 の両 エナンチオマーとも任意に高選択的に合成できるように なっている。

このようにして合成したアルデヒド 68 と Grignard 試薬の反応は期待したように高選択的に進行した(式 19,

Table 2 The results of the reaction of 68 and 72 with nucleophiles.

\begin{tabular}{c|c|c|c|l|c|c}
\hline \multirow{2}{*}{ Run } & \multicolumn{2}{|c|}{ Substrate68 or 72 } & \multirow{2}{*}{ Nucleophile } & \multicolumn{2}{|c}{ Product } \\
\cline { 6 - 7 } \cline { 5 - 6 } & $\mathrm{R}^{1}$ & $\mathrm{R}^{2}$ & $\mathrm{R}^{3}$ & & $69: 73$ & $\begin{array}{c}\text { Yield } \\
(\%)\end{array}$ \\
\hline 1 & $\mathrm{H}$ & $\mathrm{Bn}$ & & EtMgBr & $14: 1$ & 87 \\
2 & $\mathrm{H}$ & $\mathrm{Me}$ & & EtMgBr & $>99:<1$ & 92 \\
3 & $\mathrm{Bu}^{\mathrm{n}}$ & $\mathrm{Me}$ & & EtMgBr & $>99:<1$ & 82 \\
4 & $\mathrm{H}$ & $\mathrm{Bn}$ & $\mathrm{Et}$ & L-Selectride & $<1:>99$ & 91 \\
5 & $\mathrm{H}$ & $\mathrm{Me}$ & $\mathrm{Et}$ & L-Selectride & $<1:>99$ & 83 \\
6 & $\mathrm{Bu}^{\mathrm{n}}$ & $\mathrm{Me}$ & $\mathrm{Et}$ & L-Selectride & $<1:>99$ & 83 \\
\hline
\end{tabular}

表 2 )。さらに syn 型アルコール 69 をクロム酸酸化して 得られるケトン 72 の L-Selectride による還元反応む 高選択的に進行し, anti 型アルコール 73 のみを与えた (式 20, 表 2 )。

アルデヒド 68 の両エナンチオマーを原料とすること により，一般式 75〜78 で示した 1,2-ジオールの 4 種 の立体異性体の全てを作り分けることが可能となった本 反応の応用範囲は広い。<smiles>[R]C(O)[C@@H]([R])O</smiles>

75<smiles>[R]C(O)[C@@H]([R])O</smiles>

76<smiles>[R]C(O)C([Y])O</smiles>

77<smiles>[R]C(O)C([R])O</smiles>

78
3. 1. 2. ブレビコミン合成 ${ }^{45)}$ ブレビコミン (79) は 1, 2- ジオール 80 の分子内アセタール化した化合物であ る。このうち, ( $1 R, 7 R)$ の立体をもつ $(+)-e x o-79$ はキククイムシの一種 western pine beetle の性フェ

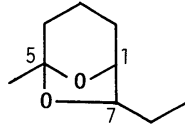

brevicomin

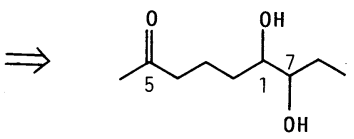

80
ロモンであり, 一方 $(1 S, 7 R)-(+)$ endo-79 ならび に (1 R, 7S)-(一)-endo-79 はアカハリモミに生息する 昆虫の集合フェロモンである ${ }^{46)}$ 。3.1. 1. で述べた反応を 使い79 のすべての立体異性体を合成することができた。 合成ルートをスキーム 23 に示す。 $(S)-68$ a と Grignard 試薬の付加反応により syn-81 が得られ, 一方, syn-81 を酸化後 L-Selectride 還元すると anti-82 が 得られた。これらの生成物は脱シリル化したのち脱アセ タール化, 脱ベンジル化ならびに二重結合の還元を行い $(1 \cdot R, 7 R)-(+)$-exo-ならびに $(1 S, 7 R)-(+)$-endo79 に変換できた。一方 $(R)-68$ a を用いることにより $(1 S, 7 S)-(-)$-exo-および $(1 R, 7 S)-($ - )-endo- 79 が合成できた。

3. 2. グリセルアルデヒドアセトニドに対する求核試 薬の付加反応 グリセルアルデヒドアセトニド(83)は 両エナンチオマーとも容易に入手し得る化合物であり各 種光学活性化合物合成のキラルな出発物質として広く用 いられている。特に 83 の $(R)$-体は D-マンニトール から 2 工程で合成でき, 安価かつ大量に入手し得る出発 質としてその応用例は多い。さて83に対し有機金属化合物 （R-M）を作用させると（式 $21 ）$ に示すように syn 型お 


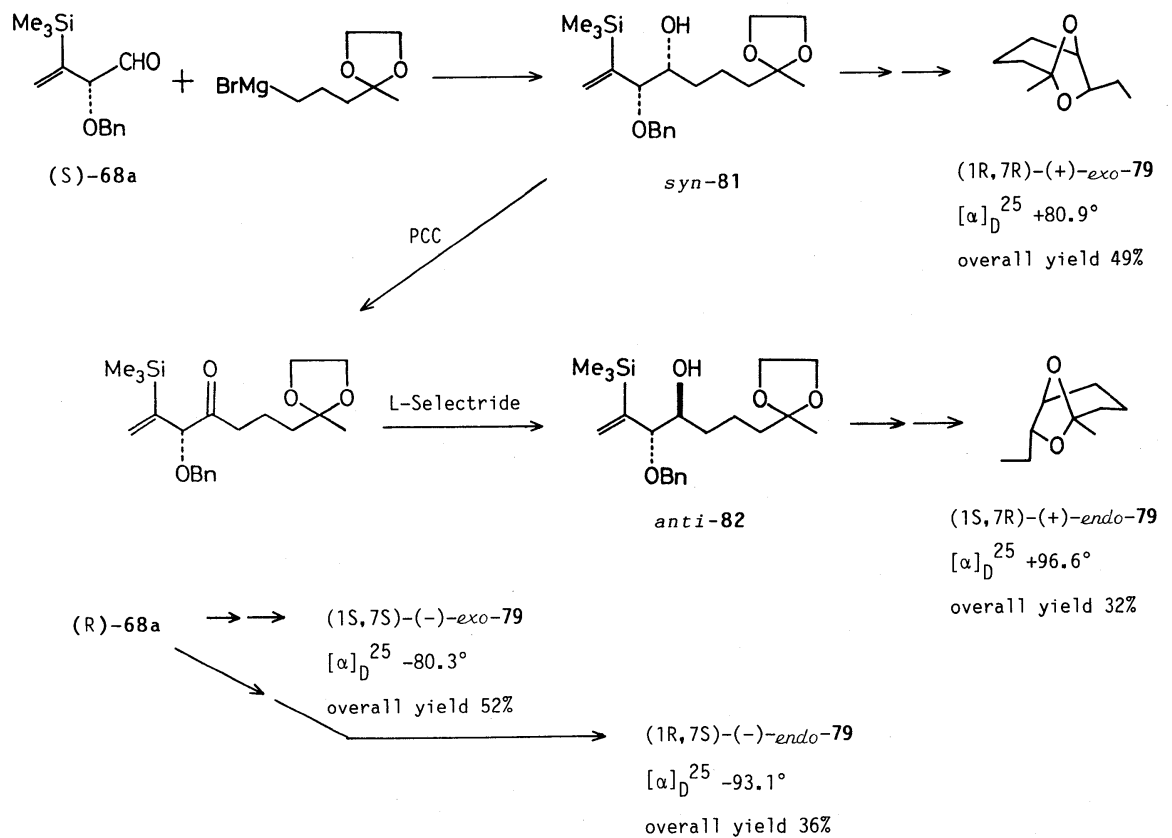

Scheme 23

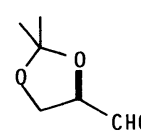

( R ) -83<smiles>CC1(C)OC[C@@H]([C@H](O)F)O1</smiles><smiles>[R]C(O)[C@H]1COC(C)(C)O1</smiles>

Table 3 Addition reaction of 83 with organometallic compounds ( $R-M)$.

\begin{tabular}{|c|c|c|c|}
\hline \multirow[t]{2}{*}{$\mathrm{R}-\mathrm{M}$} & $\begin{array}{c}\text { Product } \\
\text { ratio }\end{array}$ & $\begin{array}{c}\text { Yield } \\
(\%)\end{array}$ & \multirow{2}{*}{ Ref. } \\
\hline & $84: 85$ & $84+85$ & \\
\hline $\mathrm{MeMgBr}$ & $33: 67$ & 57 & 48 \\
\hline $\mathrm{Bu}^{\mathrm{n}} \mathrm{Li}$ & $31: 69$ & 83 & 48 \\
\hline $\mathrm{Bu}^{\mathrm{n}} \mathrm{MgBr}$ & $25: 75$ & 86 & 48 \\
\hline $\mathrm{Bu}^{\mathrm{n}} \mathrm{Ti}\left(\mathrm{OPr}^{\mathrm{i}}\right)_{3}$ & $10: 90$ & 40 & 48 \\
\hline $\mathrm{CH}_{2}=\mathrm{CHMgCl}$ & $40: 60$ & 65 & 49 \\
\hline$\left(\mathrm{CH}_{2}=\mathrm{CHCH}_{2}\right)_{2} \mathrm{Zn}$ & $9: 91$ & 65 & 48 \\
\hline $\operatorname{ImdOCH}=\mathrm{CHCH}_{2} \mathrm{CdI}$ & $0: 100$ & 62 & 50 \\
\hline$+\mathrm{ZnBr}_{2}$ & $<5:>95$ & 75 & 51 \\
\hline & & & \\
\hline
\end{tabular}

よび anti 型付加物の 2 つの立体異性体が生成する。こ こで, この反応の立体化学が制御でき, syn 型あるいは $a n t i$ 型付加物を任意に選択性高く合成することができれ ば合成的意義は大きい。最近になってこの問題が重要な 研究課題としてとりあげられるようになってきた ${ }^{47)}$ 。そ れらの研究結果を表 3 に示した。反応は Felkin-Anh model あるいはアルデヒドカルボニル酸素と $\beta$ 位の酸 素とのキレーションを考えた Cram の cyclic model に 従い（図 3，86）ほとんどの場合 anti-85 を優先して与 える。さて, syn-84を与える遷移状態としては 83 の $\alpha$ 位の酸素とのキレーションを考えたモデル（図 3,87） が考えられるが，これまでのところ syn-84 を選択性高 く得ることには成功していなかった。そこで前述した Still らの結果をもとに, 即ち $\alpha$-ベンジルオキシアルデヒド

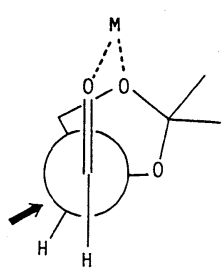

86

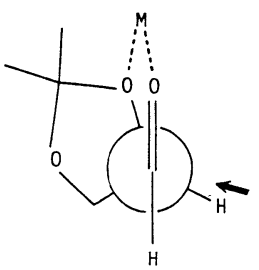

87
Fig. 3 
Table 4 Addition products 84 and 85 obtained by the reaction of organocopper compounds with $(R)-83^{\mathrm{a}}$.

\begin{tabular}{|c|c|c|c|c|c|}
\hline \multirow{2}{*}{ Run } & \multicolumn{2}{|c|}{$\mathrm{RCu}^{\mathrm{b})}$} & \multirow{2}{*}{$\frac{\text { Yield }(\%)^{\mathrm{c})}}{84+85}$} & \multirow{2}{*}{\multicolumn{2}{|c|}{$\frac{\text { Product } \text { ratio }^{\text {d), e ) }}}{84: 85}$}} \\
\hline & Compound & $\mathrm{R}$ & & & \\
\hline 1 & a & $n-\mathrm{C}_{4} \mathrm{H}_{9}$ & 75 & $16: 1$ & $(1: 2.4)$ \\
\hline 2 & b & $c-\mathrm{C}_{6} \mathrm{H}_{11}$ & 75 & $10: 1$ & $(1: 1.4)$ \\
\hline 3 & c & $\mathrm{Ph}$ & 91 & $>99: 1$ & $(1.8: 1)$ \\
\hline 4 & d & $\mathrm{Ph}-p-\mathrm{MeO}$ & 80 & $>99: 1^{(\mathrm{f}), \mathrm{g})}$ & $(2.3: 1)$ \\
\hline 5 & e & $\mathrm{Ph}-p^{-} \mathrm{Cl}$ & 93 & $>99: 1$ & $(2: 1)$ \\
\hline 6 & $f$ & $\mathrm{CH}_{2}=\mathrm{C}\left(\mathrm{SiMe}_{3}\right)$ & 86 & $>98: 2^{\mathrm{f})}$ & $(1: 1.7)$ \\
\hline
\end{tabular}

a) The reactions were carried out in $\mathrm{THF}-\mathrm{Me}_{2} \mathrm{~S}$ at $-78^{\circ} \mathrm{C} \longrightarrow$ room temperature $(2 \mathrm{~h})$. b) Prepared from $\mathrm{RMgBr}$ and $\mathrm{CuI}$. c) Isolated yields. d) Determined by glc analysis after converting to the corresponding methyl ethers for run 1 and 2, and by ${ }^{1} \mathrm{H}$ NMR spectroscopy for run 3-6. e) The ratios within the parentheses were obtained by the reaction with Grignard reagents in THF. f) The same ratio was obtained when the reaction was carried out at $-15{ }^{\circ} \mathrm{C}$. g) The ratio was lowered to $4: 1$ when the reaction was carried out in $\mathrm{Et}_{2} \mathrm{O}-\mathrm{Me}_{2} \mathrm{~S}$.
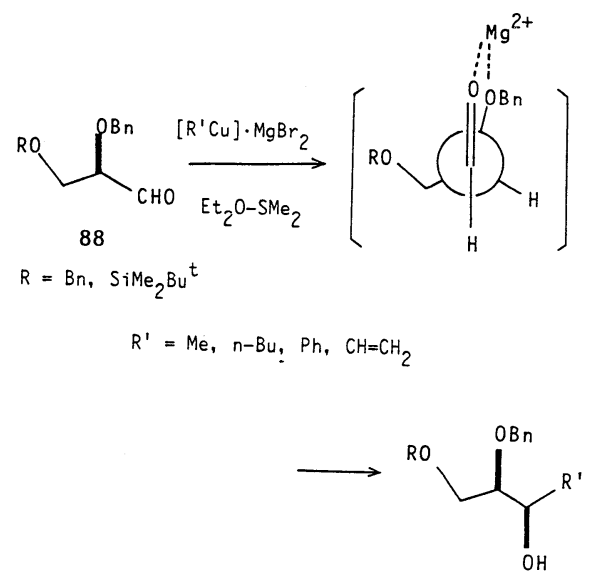

syn-selectivity

$>93 \%$

と Grignard 試薬の反応で高選択的に syn-84 が得られ るという結果をもとに $\alpha$-ベンジルグリセルアルデヒド 88 と有機金属化合物の反応が検討された。そしてこの場合は 高い選択性が得られるということが最近になって明らか
にされた（式 22$)^{52)}$ 。我々はこのような状況を子まえ， なんとかして入手しやすい 83 との直接の反応で syn 付 加物を得ようと努力した。その結果, Grignard 試薬と $\mathrm{CuI}$ の反応で得られる有機銅化合物が THF 溶媒中83 反応して高選択的に syn-84 を与えることを見出した(式 $23)^{53)}$ 。結果を表 4 に示す。アルキル, アリール, ビニ ル銅, いずれの場合も高い選択性が得られ, 従来合成が 困難であった syn-84 が得られる本反応の合成的意義は 大きいといえよう。

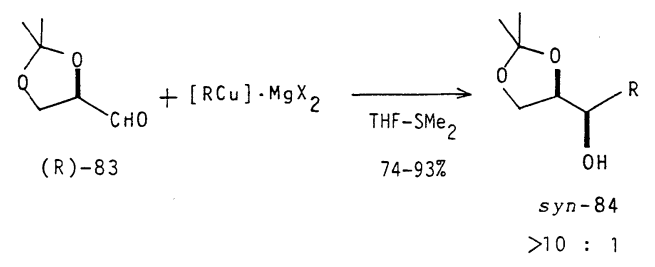

このようにして得られた syn-84 はスキーム 24 に示 すように容易にエポキシアルコール 89 および 90 に導

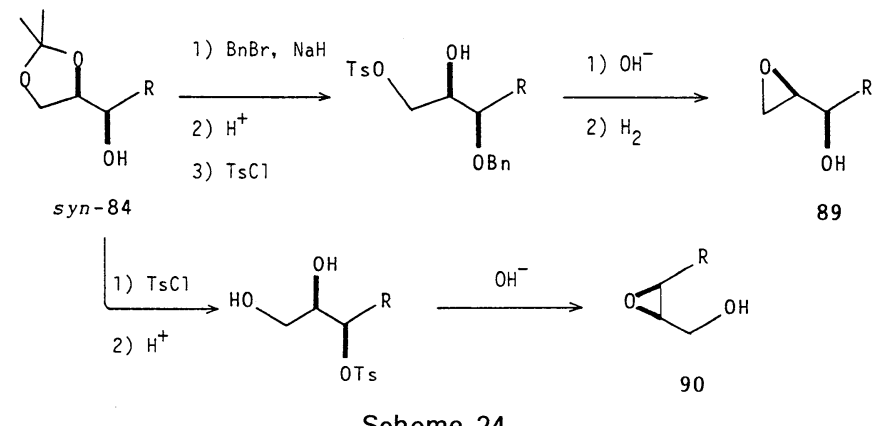

Scheme 24 
くことができる。エポキシアルコールは合成上有用な中 間体であり，その合成に関しては不斉 Sharpless 反 応 ${ }^{54)}$ がよく用いられているが，この不斉Sharpless 反応 では直接合成できない立体化学を有する syn 型エポキシ アルコール (89), あるいは不斉収率に問題が残されて いる cis-エポキシアルコール (90) が合成できるこの反 応も今後相補的に利用されると期待できる。また 83 と 1-トリメチルシリルビニル銅との syn 型付加物 $84 \mathrm{f}$ を $\mathrm{VO}(\mathrm{acac})_{2}$ を触媒として TBHP 酸化すると高い不斉誘 導 ${ }^{55)}$ が抽こりスキーム 25 に示した立体化学をもつ化合
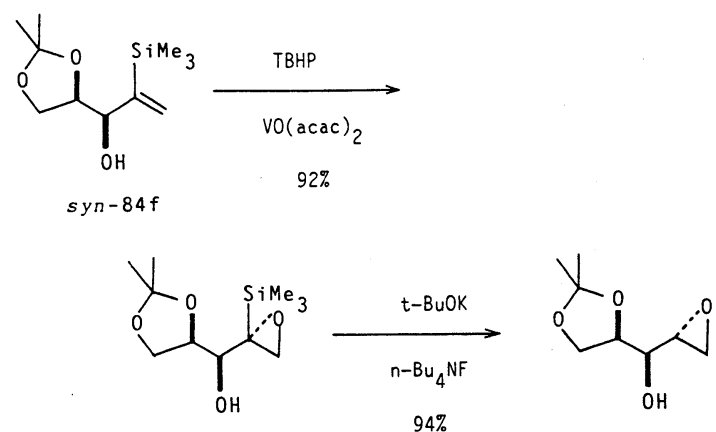

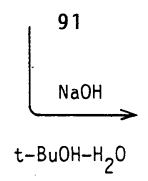

$87 \%$

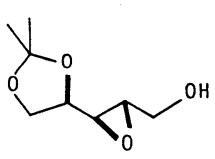

93

Scheme 25

物 91 のみが得られた。91に THF 中， $t-\mathrm{BuOK}, n-$ $\mathrm{Bu}_{4} \mathrm{NF}$ を $0{ }^{\circ} \mathrm{C}$ で作用させると定量的にプロト脱シリル 化がおこり 92 をまた 91 に $t-\mathrm{BuOH}$ 中 $\mathrm{NaOH}$ を作用 させるとプロト脱シリル化-Payne 転位が起こり93を与 えた。このようにして得られた化合物 92 および 93 は単

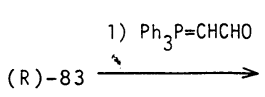

2) DIBAL $85 \%$

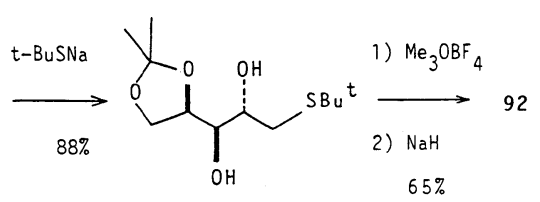

糖類合成の有用な中間体になることが Sharpless - 正宗 らにより示されている。なお，Sharpless-正宗らによる 化合物 92 および 93 の合成ルートをスキーム 26 に示 した ${ }^{56)}$ 。

また 3. 1. 1. で述べたように化合物 $84 \mathrm{f}$ は vicージオー ルの選択的合成上有用な出発物質である $\alpha$-アルコキシ$\beta$-トリメチルシリルー $\beta, \gamma$-不飽和アルデヒド $(S)-68$ に 容易に導ける（式 19，20）。

さて syn-84fのジアステレオマー, 即ち ant $i$ 型付加 物 $85 \mathrm{f}$ が得られるならば，92, 93 のジアステレオマー や $(S)$-68 のエナンチオマーを合成することができる。始 め我々は前述したように 83 と有機金属との反応でanti85 を選択性高く与える条件が既にいろいろと知られて いるので，そのような条件下で反応を行い anti-85f を 得ようとした。実際にいくつかの条件下で反応を検討し たところ，anti- $85 \mathrm{f}$ を優先的に得ることはできたが， 選択性は $3: 1$ 程度であり, 必ずしも満足のいくもので はなかった（式 24）。それゆえ, 新しい反応条件を検討<smiles>C=C(N)[As][Te]</smiles><smiles>C=C(S[13CH3])[C@@H](O)C1COC(C)(C)O1</smiles>

syn- $84 f$ anti-85f

$$
\begin{array}{ll}
M=M g \text { in THF-HMPA } & 1: 3 \\
M=T i(0 i-P r)_{3} \text { in } E t_{2} O & 1: 3
\end{array}
$$

した。その結果, 幸運なことに $\mathrm{CuCN}$ と 1-トリメチル シリルビニルマグネシウムブロミドから合成した high<smiles>[R]C=C([AsH2])C(=O)[18OH]</smiles>

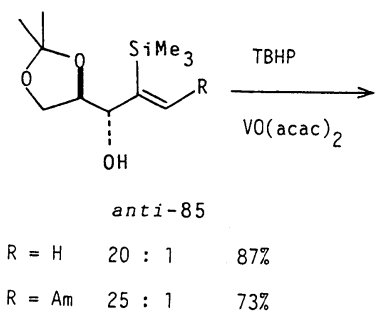

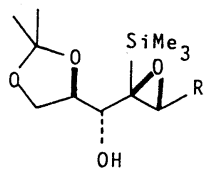

94

Scheme 26 
order mixed cuprate が高い選択性で anti-85 を与える ことを見出した ${ }^{57)}$ 。そしてこのようにして得られた anti85 の TBHP/VO (acac) 2 によるエポキシ化反応も予想ど おりほぼ $100 \%$ の選択性で進行し 94 を与えた（スキー 厶 27)。

\section{4. おわりに}

本論文では光学活性カルボニル化合物と有機金属の反 応を高立体選択的に実現し, これら反応生成物を光学活 性天然化合物合成に応用することを目的とし 3 年程前か ら筆者らが取り組んできた研究について述べた。古くか ら研究されているこの種の反応が, 現在有機合成の分野 で一つのトピックスとなっているマクロリドやイオノホ ールなどの合成に応用できる鎖状化合物の立体制御法と して有用であることを示すことができた。このように筆 者らが研究初期に考えた以上の成果が得られたことは幸 運であったとともに協同研究者のたゆみない努力のおか げであったと感謝している。最近 $\alpha$-アルキル置換カルボ ニル化合物への求核試薬の付加の立体化学が Grignard 試 薬/有機アルミニウム化合物 ${ }^{58)}$ あるいはクプラート/クラ ウンエーテル ${ }^{59}$ ) 等の複合試薬を用いると逆転することが 明らかにされた。機構的にも，また合成への応用の面で も新らしい展開を見せているこの分野の化学が今後も大 きく発展すると期待している。

（昭和 61 年 2 月 8 日受理）

\section{文献}

1) D. J. Cram, F. A. Abd Elhafez, J. Am. Chem. Soc., 74, 5828 (1952) ; D. J. Cram, K. R. Kopecky, ibid., 81, 2748 (1959) ; D. J. Cram, D. R. Wilson, ibid., 85, 1245 (1963) ; J. D. Morrison, H. S. Mosher, "Asymmetric Organic Reactions", Prentice-Hall, New Jersey (1971)

2) M. Chérest, H. Felkin, N. Prudent, Tetrahedron Lett., 1968, 2199 ; N. T. Anh, O. Eisenstein, Nouv. J. Chim., 1, 61 (1977)

3) E. L. Eliel, "Asymmetric Synthesis" (J. D. Morrison ed.), Vol. 2, Chapter 5, Academic Press (1983)

4) P. A. Bartlett, Tetrahedron, 36, 2 (1980); “中・大環状天然物合成の新展開”（日本化学会 編), 化学総説, 31，(1981）; 村田静昭, 野依良 治，化学の領域, 35, 856, 938 (1981); I. Paterson, M. M. Mansuri, Tetrahedron, 41, 3569 (1985)

5) E. W. Colvin, "Silicon in Organic Synthesis", Butterworths, London (1981); W. P. Weber, "Silicon Reagents for Organic Synthesis",
Springer-Verlag, New York (1983)

6) F. Sato, M. Kusakabe, Y. Kobayashi, J. Chem. Soc., Chem. Commun., 1984, 1130

7a) F. Sato, J. Organometal. Chem., 285, 53 (1985)

b) F. Sato, H. Ishikawa, M. Sato, Tetrahedron Lett., 22, 85 (1981)

8a) Y. Kobayashi, Y. Kitano, F. Sato, J. Chem. Soc., Chem. Commun., 1984, 1329

b) Y. Kobayashi, Y. Kitano, Y. Takeda, F. Sato, Tetrahedron, in press

9) K. Suzuki, E. Katayama, T. Matsumoto, G. Tsuchihashi, Tetrahedron Lett., 25, 3715 (1984)

10) K. Suzuki, E. Katayama, G. Tsuchihashi, ibid., 25, 2479 (1984)

11) F. Sato, Y. Tanaka, M. Sato, J. Chem. Soc., Chem. Commun., 1983, 165

12) G. Stork, E. Colvin, J. Am. Chem. Soc., 93, 2080 (1971)

13) F. Sato, H. Ishikawa, M. Sato, Tetrahedron Lett., 21, 365 (1980)

14) F. Sato, Y. Takeda, H. Uchiyama, Y. Kobayashi, J. Chem. Soc., Chem. Commun., 1984, 1132

15) F. Sato, M. Kusakabe, T. Kato, Y. Kobayashi, ibid., 1984, 1331

16) T. Mukaiyama, Org. Reactions, 28, 203 (1982) ; C. H. Heathcock, "Asymmetric Synthesis" (J. D. Morrison ed.), Vol. 3, Chapter 2, Academic Press (1984) ; D. A. Evans, J. V. Nelson, T. R. Taber, "Top. in Stereochem." (N. L. Allinger, E. L. Eliel, S. H. Wilen eds.), Vol. 13, Chapter 1 (1982)

17a) C. H. Heathcock, M. C. Pirrung, S. H. Montgomery, J. Lampe, Tetrahedron, 37, 4087 (1981)

b) M. C. Pirrung, C. H. Heathcock, J. Org. Chem., 45, 1727 (1980)

18) K. Suzuki, E. Katayama, K. Tomooka, T. Matsumoto, G. Tsuchihashi, Tetrahedron Lett., 26, 3707 (1985)

19) A. K. Samaddar, T. Chiba, Y. Kobayashi, F. Sato, J. Chem. Soc., Chem. Commun., 1985, 329

20) Y. Kobayashi, H. Uchiyama, H. Kanbara, F. Sato, J. Am. Chem. Soc., 107, 5541 (1985)

21）中馬達二, 有合化, 39, 1183 (1981); K. Mori, H. Nomi, T. Chuman, M. Kohno, K. Kato, M. Noguchi, Tetrahedron, 38, 3705 (1982)

22) J. J. Eish, J. E. Galle, J. Organometal. Chem., 160, C 8 (1978)

23) Y. Takeda, Y. Kobayashi, F. Sato, Chem. Lett., 1985, 471

24) E. Lederer, A. Adam, R. Ciorbaru, J. -F. 
Petit, J. Wietzerbin, Mol. and Cell. Biochem., 7, 87 (1975) ; E. Lederer, Chem. Physics of Lipids, 16, 91 (1976)

25) J. - F. Tocanne, C. Asselineau, Bull. Soc. Chim. Fr., 1968, 4519 ; C. Asselineau, G. Tocanne, J. -F. Tocanne, ibid., 1970, 1455

26) C. H. Heathcock, J. Lampe, J. Org. Chem., 48, 4330 (1983)

27) Y. Kitano, Y. Kobayashi, F. Sato, J. Chem. Soc., Chem. Commun., 1985, 498

28) G. Kunesch, P. Zagatti, J. Y. Lallemand, A. Debal, J. P. Vigneron, Tetrahedron Lett., 22, 5271 (1981) ; J. P. Vigneron, R. Meric, M. Larcheveque, A. Debal, G. Kunesch, P. Zagatti, M. Gallois, ibid., 23, 5051 (1982)

29) K. Suzuki, T. Ohkuma, G. Tsuchihashi, ibid., 26, 861 (1985)

30) M. Kinoshita, S. Aburaki, S. Umezawa, $J$. Antibiot., 25, 373 (1972)

31) H. Uchiyama, Y. Kobayashi, F. Sato, Chem. Lett., 1985, 467

32) J. R. Martin, W. Rosenbrook, Biochemistry, 6, 435 (1967)

33) S. Omura, H. Matsubara, A. Nakagawa, A. Furusaki, T. Matsumoto, J. Antibiot. Chemother. (Washington, D. C.), 33, 915 (1980)

34) Y. Kitano, M. Kusakabe, Y. Kobayashi, F. Sato, Chem. Lett., 1986, 523

35) M. Hayashi, H. Ohara, M. Ohno, H. Sakakibara, S. Satoi, K. Harada, M.Suzuki, J.Antibiot., 34, 1075 (1981)

36) K. Suzuki, K. Tomooka, T. Matsumoto, E. Katayama, G. Tsuchihashi, Tetrahedron Lett., 26, 3711 (1985)

37a) M. T. Reetz, Angew. Chem. Int. Ed. Engl., 23, 556 (1984)

b）上西潤一，大和正利，有合化，43，335 (1985)

38) T. Oishi, T. Nakata, Acc. Chem. Res., 17, 338 (1984)

39) M. Fujita, T. Hiyama, J. Am. Chem. Soc., 106, 4629 (1984) ; T. Hiyama, K. Kobayashi, M. Fujita, Tetrahedron Lett., 25, 4959 (1984)

40) M. Fujita, T. Hiyama, J. Am. Chem. Soc., 107, 8294 (1985)

41) W. C. Still, J. H. McDonald, III, Tetrahedron Lett., 21, 1031 (1980)
42) W. C. Still, J. A. Schneider, ibid., 21, 1035 (1980)

43) M. Asami, T. Mukaiyama, Chem. Lett., 1983, 93 ; M. Asami, R. Kimura, ibid., 1985, 1221

44) M. T. Reetz, K. Kesseler, S. Schmidtberger, B. Wenderoth, R. Steinbach, Angew. Chem. Suppl., 1983, 1511

45) F. Sato, O. Takahashi, T. Kato, Y. Kobayashi, J. Chem. Soc., Chem. Commun., 1985, 1638

46) U. Kohnle, J. P. Vite, Naturwiss., 71, 47 (1984); V. Schurig, R. Weber, G. J. Nicholoson, ibid., 70, 92 (1983) ; K. Mori, "The Total Synthesis of Natural Products" (J. ApSimon ed.), Vol. 4, Chapter 1 (1981)

47) G. J. McGarvey, M. Kimura, T. Oh, J. M. Williams, J. Carbohydrate Chem., 3, 125 (1984) ; 向山光昭, 正田晋一郎, 有合化, 42, 474 (1984)

48) J. Mulzer, A. Angermann, Tetrahedron Lett., 24, 2843 (1983)

49) D. J. Walton, Can. J. Chem., 45, 2921 (1967)

50) M. Yamaguchi, T. Mukaiyama, Chem. Lett., 1981, 1005 ; idem, ibid., 1982, 237

51) K. Suzuki, Y. Yuki, T. Mukaiyama, ibid., 1981, 1529

52) K. Mead, T. L. Macdonald, J. Org. Chem., 50, 423 (1985) ; M. T. Reetz, K. Kesseler, ibid., 50, 5434 (1985)

53) F. Sato, Y. Kobayashi, O. Takahashi, T. Chiba, Y. Takeda, M. Kusakabe, J. Chem. Soc., Chem. Commun., 1985, 1636

54) C. H. Behrens, K. B. Sharpless, Aldrichimica Acta, 16, 67 (1983)

55) H. Tomioka, T. Suzuki, K. Oshima, H. Nozaki, Tetrahedron Lett., 23, 3387 (1982) ; A. S. Narula, ibid., 23, 5579 (1982)

56) T. Katsuki, A. W. M. Lee, P. Ma, V. S. Martin, S. Masamune, K. B. Sharpless, D. Tuddenham, F. J. Walker, J. Org. Chem., 47, 1373 (1982)

57) M. Kusakabe, S. Okamoto, Y. Kitano, T. Shimazaki, Y. Takeda, F. Sato, to be published

58) K. Maruoka, T. Itoh, H. Yamamoto, J. Am. Chem. Soc., 107, 4573 (1985)

59) Y. Yamamoto, K. Maruyama, ibib., 107, 6411 (1985) 